Acta vet. scand. 1961, 2, 15-21.

From the Department of Chemistry and the Department of Bacteriology, Royal Veterinary College, Stockholm.

\title{
COMPARISON \\ OF THE HAEMOLYTIC PROPERTIES \\ OF BACILLUS CEREUS AND BACILLUS ANTHRACIS
}

By

W. Thorsell and B. K. Nordberg

The haemolytic property of B. cereus is often utilised as one of the criteria for distinguishing between this organism and the closely related B. anthracis (Topley \& Wilson 1955, Hallman 1955). On blood agar, however, B. anthracis often gives weak haemolysis and in our experience, haemolysis is evident when B. anthracis is cultured in an atmosphere of 21 per cent $\mathrm{CO}_{2}$.

Since the property of haemolysis may be associated with the known presence of lecithinase in these bacteria (Chu 1949, Costlow 1958, Flaschenträger \& Lehnartz 1954) it could be expected that erythrocytes containing much lecithin in their stromata, e. g. those of rabbits and human beings, would be more readily haemolysed than those containing little or no lecithin such as bovine erythrocytes (Turner 1957).

With knowledge of the complicated structure of the erythrocyte stroma (Klenk 1958, Turner 1958, Blix 1958, Spielman 1958, Klenk \& Uhlenbruck 1958, Collier 1952, Phillips \& Roome 1959) and of other components of the actual bacteria, several factors in addition to lecithinase may also be involved in producing haemolysis.

To study these possibilities, haemolysis experiments were carried out on rabbit, human, and bovine erythrocytes and paper chromatopraghy was applied to low-molecular compounds formed through the activity of $B$. cereus or B. anthracis on isolated erythrocyte stromata from rabbits, human beings and cattle. 


\section{MATERIALS AND METHODS}

Haemolytic activity was tested by exposing washed erythrocytes from heparin and citrate blood from rabbits, human beings, and cattle to cultures of B. cereus or B. anthracis grown in the serum originating from the same blood as the erythrocytes. Ten ml. 1 per cent, erythrocyte suspension were mixed with approximately $10^{3}$ organisms in $0.05 \mathrm{ml}$. $0.15 \mathrm{M} \mathrm{NaCl}$ at $37^{\circ} \mathrm{C}$. This method has been described by Jackson et al. (1957). The degree of haemolysis was estimated after $0,4,24$, and 48 hours.

Erythrocytes in $0.15 \mathrm{M} \mathrm{NaCl}$ served as controls.

"Lytic effect" on erythrocyte stromata was investigated parallel with the haemolysis experiments in the following manner.

Stromata were prepared in the manner described by Klenk et al. (1952) except that acetic acid was not used to disrupt the cell membrane. Before being tested the stromata were dialysed against distilled water at $+3^{\circ} \mathrm{C}$.

B. cereus or B. anthracis, approximately $10^{3}$ organisms in $0.05 \mathrm{ml} .0 .15 \mathrm{M} \mathrm{NaCl}$ cultivated as described above, were incubated at $37^{\circ} \mathrm{C}$ for 24 hours together with $2.5 \mathrm{ml}$. approximately 3 per cent, w/v, stroma suspension in $1 / 30 \mathrm{M}$ phosphate buffer at $\mathrm{pH}$ 7.0. After incubation the mitxures were dialysed at $+3^{\circ} \mathrm{C}$ against $100 \mathrm{ml}$. distilled water for 24 hours. The outer solution was then evaporated at $37^{\circ} \mathrm{C}$ to a volume of $0.5 \mathrm{ml}$. Of this, $0.01 \mathrm{ml}$. was studied by paper chromatography with butanol, propanol, and $\mathrm{HCl}$ as solvent system (Svennerholm \& Svennerholm 1958). In order to show the occurrence of amino acids, carbohydrates and their derivatives the strips were developed with ninhydrin (Block, Durrum \& Zweig 1958), benzidine (Horrocks, 1949), resorcinol (Svennerholm \& Svennerholm 1958), and p-dimethylaminobenzaldehyde both directly, A, (Svennerholm \& Svennerholm 1958) and after treatment with acetylacetone, B, (Partridge 1948). The chromatograms were also evaluated in UV at $240-260 \mathrm{~m}_{\mu}$.

Control series were run on stromata and bacteria separately.

\section{RESULTS}

Haemolysis after 24 hours is expressed in per cent in Table 1. The table also includes information on the length of time the bacteria were sub-cultured before being used in the haemolysis experiments and whether or not $B$. anthracis was encapsulated.

Haemolysis was invariably greater for B. cereus throughout 
Table 1. Haemolytic activity expressed in per cent.

\begin{tabular}{lccc}
\hline Erythrocytes & $\begin{array}{c}\text { Cultivation time } \\
\text { in hours for } \\
\text { the bacteria }\end{array}$ & \multicolumn{2}{c}{ Haemolysis, per cent } \\
\cline { 3 - 4 } & $\left.5^{1}\right)$ & 100 & 69 \\
\hline Rabbit & $\left.12^{1}\right)$ & 98 & 13 \\
& 12 & 97 & 0 \\
Human & $\left.5^{1}\right)$ & 98 & 2 \\
& $\left.12^{1}\right)$ & 82 & 66 \\
Bovine & 5 & 63 & 1 \\
& $\left.8^{1}\right)$ & 4 & 2 \\
& $\left.12^{1}\right)$ & 69 & 0 \\
\hline
\end{tabular}

1) B. anthracis, encapsulated.

the series. Encapsulated B. anthracis exercised a greater haemolytic effect than non-encapsulated forms. Bovine erythrocytes were not haemolysed by the organisms to the same extent as rabbit and human erythrocytes.

T a b l e 2. Rf-values of low-molecular compounds formed in systems of erythrocyte stromata and bacteria.

\begin{tabular}{|c|c|c|c|c|c|c|c|c|c|}
\hline \multirow{2}{*}{$\begin{array}{l}\text { Erythro- } \\
\text { cyte } \\
\text { stromata }\end{array}$} & \multirow[t]{2}{*}{ Organism } & \multirow{2}{*}{$\begin{array}{l}\text { Haemo- } \\
\text { lysis } \\
\text { per cent }\end{array}$} & \multirow{2}{*}{$\begin{array}{c}\text { Nin- } \\
\text { hydrin } \\
\text { (violet) }\end{array}$} & \multirow{2}{*}{$\begin{array}{c}\text { Ben- } \\
\text { zidine } \\
\text { (brown) }\end{array}$} & \multirow[t]{2}{*}{$\begin{array}{l}\text { Resor- } \\
\text { cinol }\end{array}$} & \multicolumn{3}{|c|}{$\begin{array}{l}\text { p-dimethylamino- } \\
\text { benzaldehyde }\end{array}$} & \multirow[t]{2}{*}{ UV } \\
\hline & & & & & & $\mathbf{A}$ & B & & \\
\hline \multirow[t]{6}{*}{ Rabbit } & B. cereus & 100 & $\left.0.52^{2}\right)$ & - & - & - & 0.08 & pink & 0.80 \\
\hline &, & 97 & $\left.0.51^{2}\right)$ & - & - & - & 0.09 & , & 0.83 \\
\hline & , & 98 & $\left.0.54^{1}\right)$ & - & - & - & 0.08 & , & 0.81 \\
\hline & B. anthracis & 69 & $\left.0.52^{2}\right)$ & 0.27 & - & - & 0.08 & & - \\
\hline & , & 0 & $\left.0.52^{2}\right)$ & 一 & - & - & $\left.0.10^{1}\right)$ & & - \\
\hline & 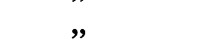 & 13 & 0.53 & - & - & - & $\left.0.10^{1}\right)$ & 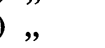 & - \\
\hline \multirow[t]{4}{*}{ Human } & B. cereus & 98 & - & - & - & - & - & & $\left.0.79^{1}\right)$ \\
\hline & , & 82 & $\left.0.52^{1}\right)$ & - & - & - & - & & - \\
\hline & B. anthracis & 2 & - & - & - & - & - & & - \\
\hline & ” & 66 & 0.52 & - & - & - & - & & - \\
\hline \multirow[t]{6}{*}{ Bovine } & B. cereus & 63 & 0.54 & 一 & - & - & 0.80 & $\begin{array}{l}\text { yellow } \\
\text { brown }\end{array}$ & 0.80 \\
\hline & , & 4 & 0.52 & - & - & - & 0.78 & , & 0.79 \\
\hline & , & 69 & 0.54 & - & - & - & 0.80 & , & 0.80 \\
\hline & B. anthracis & 1 & 0.53 & - & - & - & - & & - \\
\hline & ”, & 2 & - & - & - & - & - & & - \\
\hline & " & 0 & $\left.0.56^{1}\right)$ & - & - & - & - & & - \\
\hline
\end{tabular}

1) weak reaction.

2) faint spots with Rf $0.20-0.24 ; 0.33-0.36$. 
Table 2 contains the Rf-values obtained by paper chromatography of low-molecular compounds formed in systems containing erythrocyte stromata and cultures of B. cereus or B. anthracis.

It appears that mixtures of rabbit erythrocytes and B. cereus or B. anthracis contain ninhydrin-positive substance with $\mathbf{R f} \approx$ 0.52. With acetylacetone and p-dimethylaminobenzaldehyde, $\mathrm{B}$, pink spots with $\mathrm{Rf} \approx 0.09$ were obtained. Under UV, additional substance with $R f \approx 0.81$ was seen in the $B$. cereus mixtures. In the $B$. anthracis mixtures, benzidine-positive substance with $\mathrm{Rf} \approx 0.27$ was obtained.

In mixtures of human erythrocytes and the organisms, ninhydrin-positiv substance with $\mathrm{Rf} \approx 0.52$ could be demonstrated. For bovine erythrocytes and the organisms, the chromatograms were dominated by ninhydrin-positive substance with $\mathrm{Rf} 0.52-$ 0.56. With $\mathrm{B}$. cereus, there appeared substance with $\mathrm{Rf} \approx 0.80$ stainable with acetylacetone and p-dimethylaminobenzaldehyde, $B$, and substance with $R f \approx 0.80$ visible in $U V$.

\section{DISCUSSION}

If lecithinase is the only factor active in haemolysis caused by $B$. cereus or B. anthracis, then rabbit and human erythrocytes ought to be haemolysed more readily than bovine erythrocytes judging from the known amounts of lecithin in the stroma (Turner 1957). From Table 1 it is apparent that a greater degree of haemolysis was obtained for rabbit and human erythrocytes than for bovine erythrocytes which contain little or no lecithin (Turner 1957). But some haemolytic effect of $B$. cereus upon bovine erythrocytes occurred while that of $B$. anthracis was scarcely evident.

From this it would appear that something more than lecithinase in B. cereus is capable of affecting the erythrocyte stroma, possibly through a splitting of carbohydrates (Klenk \& Lauenstein 1952, Klenk \& Lempfrid 1957, Klenk \& Stoffel 1956) or proteins (Flaschenträger \& Lehnartz 1954) to allow escape of haemoglobin. No support for this could be obtained from attempts with ninhydrin, benzidine, resorcinol, p-dimethyl-aminobenzaldehyde, and UV to demonstrate low-molecular substances produced in systems with stromata of bovine erythrocytes and B. cereus. 
No positive reactions were obtained with benzidine, resorcinol, or p-dimethylaminobenzaldehyde directly, A.

Positive reactions were demonstrated in mixtures of bovine erythrocytes and $B$. cereus with ninhydrin $R f \approx 0.53$, with acetylacetone and p-dimethylbenzaldehyde, $B . R f \approx 0.80$, and in UV Rf $\approx 0.80$. Since similar reactions were seen in conjunction with as little haemolysis as 4 per cent, they are perhaps insignificant for the haemolytic process.

The ninhydrin-positive substances, $\mathrm{Rf} \approx 0.51-0.54$, and $\mathrm{UV}$ absorbing substances, $\mathrm{Rf} \approx 0.79-0.83$, seen in systems with rabbit and human erythrocytes and B. cereus may have some direct association with haemolysis even although the degree of haemolysis was great in each instance. Similary, the substance demonstrable through development with acetylacetone and pdimethylaminobenzaldehyde, $B$, with $\mathrm{Rf} \approx 0.08$ which appeared in systems with rabbit erythrocyte stromata and B. cereus may also be associated with the haemolysis process.

The haemolytic activity of $B$. anthracis may possibly be due solely to the effects of lecithinase since bovine erythrocytes were not haemolysed to any great degree. The ninhydrin-positive substances $\mathrm{Rf} \approx 0.53-0.56$ are apparently unimportant in the haemolytic process.

The experiments with rabbit and human erythrocyte stromata and $B$. anthracis indicate that additional factors may be involved in haemolysis. Substances reacting with ninhydrin, acetylacetone, and p-dimethylaminobenzaldehyde, B, were seen in systems with rabbit erythrocyte stromata at heamolysis ranging from 0 to 69 per cent, but benzidine-positive substances were demonstrated only in conjunction with a great degree of haemolysis. This latter substance, possibly carbohydrate in nature, may thus be directly associated with the haemolytic process.

For the same reason, the presence of ninhydrin-positive substance with $\mathrm{Rf} \approx 0.52$, possibly of amino acid nature, demonstrated in conjunction with a great degree of haemolysis of human erythrocytes may also be assumed to be closely associated with the haemolytic process. 
REFERENCES

Blix, G.: Sialic Acids, in Symposium 1, IV Int. Congress of Biochemistry, Vienna 1958.

Block, R. J., E. L. Durrum \& G. Zweig: A Manual of Paper chromatography \& Paper electrophoresis. 1958.

Chu, H. P.: J. gen. Microbiol. 1949, 3, 255.

Collier, H. B.: J. gen. Physiol. 1952, 35, 617.

Costlow, R. D.: J. Bacteriol. 1958, 76, 317.

Flaschenträger, B. \& E. Lehnartz: Physiologische Chemie. 1954, 2. Band: 1. Teil, Bandteil a, 419, 443.

Hallman, L.: Bakteriologie und Serologie, 2. Aufl. 1955, 306.

Horrocks, R. H.: Nature 1949, 164, 444.

Jackson, A. W. \& R. M. Little: Canad. J. Microbiol. 1957, 3, 47.

Klenk, E.: in Ciba Foundation Symposium: Chemistry and Biology of Mucopolysaccarides London 1958.

Klenk, E. \& K. Lauenstein: Z. physiol. Chem. Hoppe-Seyler's. 1952, $291,249$.

Klenk, E. \& H. Lempfrid: Z. physiol. Chem. Hoppe-Seyler's 1957, 307, 278.

Klenk, E. \& W. Stoffel: Z. physiol. Chem. Hoppe-Seyler's. 1956, 303, 78.

Klenk, E. \& G. Uhlenbruck: Z. physiol. Chem. Hoppe-Seyler's 1958, $311,227$.

Partridge, S. M.: Biochem. J. 1948, 42, 238.

Phillips, G. B. \& N. S. Roome: Proc. Soc. Exp. Biol. Med. 1959, 100, 489. Spielmann, W.: Dtsch. med. Wschr. 1958, 83, 2330.

Svennerholm, E. \& L. Svennerholm: Nature 1958, 181, 1154.

Topley \& Wilson: Principles of Bacteriology and Immunity. 4 Edition $1955,963$.

Turner, J. C.: J. exp. Med. 1957, 105, 189.

Turner, J. C.: Arch. internat. Med. 1958, 101, 310.

\section{SUMMARY}

The ability of B. cereus or B. anthracis to haemolyse erythrocytes from rabbits, human beings, and cattle and the effect of these organisms upon isolated erythrocyte stromata from these species have been studied. Rabbit and human erythrocytes are haemolysed by both organisms. B. cereus regularly displayed a greater haemolytic activity. Encapsulation appears to be correlated with the haemolytic activity of B. anthracis. The haemolytic property of the organisms has been associated with their lecithinase content. Since bovine erythrocytes, claimed to contain little or no lecithin, are also haemolysed, other factors perhaps contribute towards the haemolytic activity of B. cereus. Experiments with B. cereus and erythrocyte stromata indicate that the formation of low-molecular carbohydrates, amino acids, or similar compounds do not directly contribute towards haemolysis. In systems with B. anthracis and rabbit or human erythrocyte stromata were demonstrated benzidine-positive and ninhydrin-positive substances respectively which may be associated with the haemolytic process. 


\title{
ZUSAMMENFASSUNG
}

Vergleichende Studien über das hämolytische Vermögen der Bacillus cereus und Bacillus anthracis.

Beide Mikroorganismen hämolysieren Blutkörperchen von Kaninchen und Menschen mehr ausgeprägt als solche von Rindern. B. cereus zeigt das grösste hämolytische Vermögen. Das Hämolysevermögen bei B. anthracis scheint in Zusammenhang mit der Kapsel zu stehen. Es wird vermutet, dass mehrere Faktoren, ausser Lecithinase, bei der Hämolyse mitwirken. Versuche mit B. cereus und Erythrocythenstroma scheinen nicht zu zeigen, dass niedrigmolekulare Kohlenhydrate, Aminosäuren oder ähnliche Verbindungen direkt mit der Hämolyse im Zusammenhang stehen. Dagegen ist es möglich, dass in Systemen mit B. anthracis und Blutkörperchenstromata von Kaninchen bzw. Menschen die gefundene benzidinpositive, bzw. die ninhydrinpositive Substanz im Zusammenhang mit der Hämolyse stehen.

\begin{abstract}
SAMMANFATTNING
Jämförande studier över hemolytisk förmåga hos Bacillus cereus och Bacillus anthracis.

Blodkroppar från kanin och homo hemolyseras lättast av båda mikroorganismerna. Genomgående visar B. cereus den kraftigare hemolysförmågan. B. anthracis synes utöva sin hemolytiska verkan kapselförsedd. Hemolysförmågan har satts i samband med mikrobernas lecitinashalt. Då erythrocyterna från nöt trots uppgift om ringa eller ingen lecitinhalt likväl hemolyseras, bidrager troligen även andra faktorer till hämolysförloppet hos B. cereus. Försöken med B. cereus och erythrocytstromata talar för bildandet av lågmolekylära kolhydrat, aminosyror eller likartade föreningar, som ej direkt anknyta till hemolysförloppet. Däremot synes den i system med B. anthracis och erythrocytstromata från kanin funna benzidinpositiva, samt den ninhydrinpositiva substansen i system med erythrocytstromata från homo ha samband med hemolysförloppet.
\end{abstract}

(Received October 5. 1960). 